\section{Clash of symbols}

\section{Peter Kemp}

Einstein's Monsters. By Martin Amis. Jonathan Cape, London/Crown, New York: 1987. Pp. 127. £5.95, \$12.95.

BROODING over nuclear weapons has made Martin Amis's imagination mutate, he claims. Breeding a family has played its part too. As his introduction to the five fables collected in Einstein's Monsters explains, perusal of Jonathan Schell's grim forecast of nuclear holocaust, The Fate of the Earth, alerted him to looming danger, while the birth of his two children - awakening protective instincts in a writer who earlier turned out ostentatiously callous novels with titles such as Dead Babies - only increased his anxiety.

Belatedly becoming aware of the nuclear menace in 1984 at the age of 35, Amis now proclaims it with near-adolescent raucousness. Previously keen on presenting himself as a knowing habitué of the lurid, high-risk zones of London or New York, he uses this book to flash his credentials for admission to the scary sphere of nuclear nightmare. His opening polemic - couched in his customary style of finger-clicking, hard-boiled swagger enlivened by some graphic phrasing retails familiar facts about the horrendous potentialities of nuclear armaments. Some undocumented claims, as that stockpiled weapons emit radiation causing cancers, are thrown in too.

The most malign emanations from the missile silos though, are, Amis fancies, contemporary crimes of violence and sexual outrage. Nuclear armaments, "Einstein's monsters", have, he claims, made monsters of us all. Their very presence has warped humanity, generating pornography, muggings, child rape and infanticide.

This unusual objection to the megamissiles features prominently in two tales here which struggle to link twentiethcentury degeneration with nuclear arsenals. In one story, telling how a tough guy abstains from retaliation on two thugs who have randomly slaughtered his mother, daughter and granddaughter, Amis rather desperately strives for nuclear reasonance by endowing his pugnacious hero with "a neutronium fist", and sprinkling the prose with words such as "fallout" and "deterrent". Similarly strained is the symbolic background to the next piece - a forest buzzing with the "radiation" of insects, a lake oddly likened to a "warhead" - against which the schizophrenia and suicide of a nuclear physicist's son are portrayed.

The last three stories are more surreal and envisage the Earth after nuclear catastrophe. "The Little Puppy That Could", a version of the PerseusAndromeda myth, does this most extensively, evoking a garish, rotting world of hideous mutants. Many human beings are now flippered or furred. Rule is by sexually voracious matriarchal viragos with names like Keithette or Royene. Terrorizing their settlement near a stillflaming nuclear crater is a giant dog with "carcinogenic teeth", "fungoid" hair, "malarial eyes", and poisonous scarlet saliva which dissolves flesh and bone. As Amis raptly itemizes the rippings and ravagings of this grisly beast festering with anthrax, yaws, serpigo, glanders and mange - or elsewhere pores over panoramas of a mouldering, defiled planet - he reveals how little he has really changed. Like some monstrous extension of the urban cesspits that earlier engaged his interest, the prospect of terminal global pollution finally just stimulates him into another bout of his favourite fictional game: playing with putrescence.

Peter Kemp, 61 Princes Avenue, Finchley, London N3 2DA, UK, is an Associate Lecturer in English at Middlesex Polytechnic.

\section{One in the eye}

\section{Michael Nelson}

The Potato in the Human Diet. By Jennifer A. Woolfe. Cambridge University Press: 1987. Pp. 231. £17.50, $\$ 32.50$.

THE humble potato may lack the sophistication of the asparagus or the brashness of the leek, but it is firmly loved throughout the world and has an important role in human nutrition. Jennifer Woolfe has produced a remarkably readable commentary which confirms and highlights the potato's many virtues.

Following a description of the tuber components (all is not as uniform in a potato as it seems), Ms Woolfe devotes the second chapter to an extensive consideration of the nutritional value of the tuber in the forms in which it is commonly eaten. Numerous, well-constructed tables facilitate comparison of the nutrient content of the potato with staple roots and cereals and other vegetables. Discussion of the contribution of the potato to nutrient intake is uneven in its coverage, however, and might have been better as a single, more comprehensive chapter.

Chapter 3 describes potato protein quality and reviews the contribution that potato protein can make to the maintenance of nitrogen balance in both adults and children, especially in developing countries where potato is an important staple; here the author exhorts planners to consider the implications of switching to high-yield varieties with reduced protein levels. It is not clear at whom the final section on extraction of protein from potato processing waste is directed, as the process is too expensive to be of value in developing countries and too fraught with problems to be of much commercial interest elsewhere.

One-third of the book (Chapter 4) is devoted to the effects of storage, cooking and processing on the nutritive value of potatoes. This is an excellent, comprehensive review of the subject. The section dealing with domestic preparation and cooking losses will be especially valuable for those involved in nutrition education, particularly in the Third World, while that on commercial processing includes helpful summaries of large-scale processes with references for further details. The account of ways to improve yield and storage in Third World countries does not always include consideration of appropriate technology (for example irradiation to delay sprouting), and information on the increase in nutritional value of certain products with addition of vitamin $\mathrm{C}$ (instant mashed potato) or polyunsaturated fatty acids (crisps) would have been useful.

The build-up of toxins after harvesting, an important topic, is dealt with in Chapter 5, which covers the whole range of anti-nutritional factors and their potentially damaging effect on human health in areas where potato is a staple food. The book concludes with an interesting chapter on patterns of potato consumption in the tropics, with hints on how consumption can be estimated in different sections of the population.

The book is pleasingly illustrated, well laid out, thoroughly referenced and well indexed. Occasionally it reads like sales propaganda from the International Potato Center (the funding body), though this is not too obtrusive. One drawback is that no history is included, nor is there a section on trends in world potato production and consumption by region or country. Altogether, although it is not quite in the league of the FAO/WHO monographs on wheat and legumes, the book is a valuable contribution to the literature on food commodities. Nutritionists, dietitians, food planners and others with an interest in food production and supply will find it well worth reading.

Michael Nelson is a Lecturer in the Department of Food and Nutritional Sciences, King's College London (KQC), Campden Hill Road, London W8 7AH, UK

- More than compensating for the absence of history in Jennifer Woolfe's book is The History and Social Influence of the Potato by Redcliffe Salaman. The book was first published by Cambridge University Press in 1949 and was re-issued in 1985 , price pbk $£ 13.50, \$ 17.95$. 